УДК 94 (477) «1917/20...»

DOI: https://doi.org/10.33782/eminak2020.3(31).446

\title{
ПРОБЛЕМА НАЦІОНАЛЬНИХ МЕНШИН І МОВНЕ ПИТАННЯ У ПЕРІОД УКРАЇНСЬКОЇ РЕВОЛЮЦІЇ ТА СУЧАСНОЇ НЕЗАЛЕЖНОЇ УКРАЇНИ
}

\author{
Юлія Лєбєдєва \\ Науково-дослідний інститут українознавства (Київ, Україна) \\ e-mail: lebedeva-yuliya@ukr.net \\ ORCID: https://orcid.org/0000-0003-0628-0309
}

У статті розвивається теза щодо зумовленості проблеми національних меншин у період Украӥнської національної революції та незалежної України на сучасному етапі необхідністю збереження самоідентифікації як українців, так і інших національних меншин в умовах збереження державності. Вказується на залежність вирішення питання національних меншин в Украӥнській Народній Республіці від позиції Тимчасового уряду та більшовиків. Визначені фактори, які впливають на усунення розбіжностей у національному питанні у незалежній Україні на сучасному етапі.

Ключові слова: національні меншини, мовне питання, Українська революція, незалежна Україна, демократія, ліберальні засади

Актуальність теми зумовлюється необхідністю збереження суверенітету України у ході «гібридної війни». На сучасному етапі українська влада враховує здобутки та прорахунки досвіду Української національної революції, під час якої існувала загроза української державності. Важливим завданням мовного та національного питання $€$ протистояння наслідкам русифікації українців, запобігання поширенню цього явища та залучення національних меншин до державотворення. Розвиток національних меншин згідно з законодавством повинен відповідати інтересам української влади з огляду на збереження національної та культурної ідентичності українців. Тому саме необхідність розвитку панівної нації та запобігання сепаратизму $є$ основними завданнями національного та мовного питання.

Аналіз національного та мовного питання в період Української революції варто проводити шляхом дослідження документів, створених органами української влади. Цінним джерелом, в якому відображається питання національних меншин, $є$ тритомна праця В. Винниченка «Відродження нації»1. У книзі висвітлюється провладна позиція щодо надання культурної автономії національним меншинам. Відомі збірники документів, де присутні накази й розпорядження органів влади періоду Української Центральної Ради та Директорії УНР2. У «Спогадах» П. Скоропадського інфор-

\footnotetext{
${ }^{1}$ Винниченко В. Відродження нації. Частина І. Київ Відень: Видавництво «Дзвін», 1920. 348 с.; Винниченко В. Відродження нації (Історія української революції [марець 1917 р. - грудень 1919 р.]). Частина II. Київ - Відень: Видавництво «Дзвін», 1920. 328 с.; Винниченко В. Відродження нації (Історія української революції [марець 1917 р. - грудень 1919 р.]). Частина III. Київ-Відень: Видавництво «Дзвін», 1920. 535 с.

2 Директорія, Рада Народних Міністрів Української Народної Республіки. Листопад 1918 - листопад 1920 рр.: Док. і матеріали. У 2-х томах, 3-х частинах. Т. 1 / Упоряд.: В. Верстюк (керівник) та ін. Київ: Видавництво імені Олени Теліги, 2006. 687 с.; Ткаченко Є.В. Правовий захист прав етнічних та мовних меншин. Навчальний посібник. Київ, 2018. 315 с.; Українська Центральна Рада. Документи і матеріали. У двох томах. Т. 1. 4 березня - 9 грудня 1917 р. / Смолій В.А. (відп. ред.); Верстюк В.Ф. (упоряд.). Київ: Наукова думка, 1997. 588 с.
} 
мується про значення проросійської еліти у політичній діяльності гетьманаз часному етапі на вирішення національного питання в Україні вплинули міжнародні та європейські нормативно-правові акти, створені у дусі ліберальних засад, зокрема, Декларація принципів толерантності4, Гаазькі рекомендації щодо прав національних меншин на освіту5, Рамкова конвенція Ради Європи про захист національних меншин 6 . Питання національних меншин і мовна проблема вирішується шляхом практичної реалізації українського законодавства, зокрема Закону України «Про національні меншини»7, Закону України «Про забезпечення функціонування української мови як державної»8.

Національне та мовне питання періоду Української національної революції досліджується у працях Д. Яневського 9 та В. Устименка 10 . У першій праці вміщене законодавство українських урядів упродовж 1917-1923 рр., у тому числі з проблем національних меншин і мовного питання. Однак виклад матеріалу в монографії у контексті даного дослідження є досить побіжним. В. Устименко аналізує відмінності законодавчої бази Української Центральної Ради та Директорії Української Народної Республіки, охоплюючи тему єврейських погромів і ставлення до вказаної народності українських урядів. Проблема національних меншин у незалежній Україні на сучасному етапі проаналізована у дослідженнях О. Калакури ${ }^{11}$ та Ю. Лихач 12.

У сучасних дослідженнях представників народностей і націй, які проживають на території України на сучасному етапі, присутні тези про поміркованість українського уряду в вирішенні національного питання, що розходиться з потребами окремих громадян України, особливо націоналістів і сепаратистів. Ю. Лихач акцентує увагу на орієнтацію українського уряду на європейські норми, тому важливим питанням $\epsilon$ пристосування законодавства Європейського Союзу до умов незалежної України. Мовне питання на території держави на сучасному етапі вивчають Д. Абрамова 13 та

\footnotetext{
3 Скоропадський П. Спогади. Кінець 1917 - грудень 1918 / Гол. ред. Ярослав Пеленський. КиївФіладельфія, 1995. 493 с.

${ }^{4}$ Декларація принципів толерантності (Ред. від 16.11.1995). URL: https://zakon.rada.gov.ua/laws/show/995_503

5 Гаазькі рекомендації щодо прав національних меншин на освіту та пояснювальна записка. 1996. $22 \mathrm{c}$.

6 Друга доповідь України про виконання Рамкової конвенції Ради Європи про захист національних меншин. Київ, 2006. 63 с.

7 Закон України «Про національні меншини» // Відомості Верховної Ради України. 1992. № 36. C. 529.

8 Закон України «Про забезпечення функціонування української мови як державної» // Відомості Верховної Ради. 2019. № 21. С. 81.

9 Яневський Д. Політичні системи України 1917-1920 років: спроби творення і причини поразки. Київ: Дух і Літера, 2003.

10 Устименко В. Етнополітичний фактор в політиці Директорії УНР // Проблеми вивчення історії Української революції 1917-1921 років. 2010. № 5. С. 207-256; Устименко В. Формування правничої бази для регулювання міжетнічних відносин у період Української Центральної Ради // Український історичний журнал. 2012. № 1. С. 79-88.

11 Калакура О. Правовий статус етнічних меншин України // Етнічна історія Європи. 2000. Вип. 4. C. $109-114$.

12 Лихач Ю. Актуальні проблеми законодавчого забезпечення прав національних меншин в Україні ІПіЕНД ім. І.Ф. Кураса НАН України // Наукові записки. 2010. Вип. 3 (47). С. 27-37.

${ }^{13}$ Абрамова Д. Правове регулювання державної мовної політики у сфері захисту прав національних меншин // Геополітика України: історія і сучасність. Збірник наукових праць. 2019. Вип. 1 (22). С. 226-261.
} 
О.А. Матета ${ }^{14}$.

У період незалежної України, як вказується у працях сучасних істориків, спостерігався відхід від русифікаційної політики та береться курс на збереження суверенітету, однак намагання співпраці з національними меншинами у питанні державотворення сприяє низці поступок, що негативно сприймається власне українцями. O.А. Матета наводить ряд прикладів, які можуть стати визначальними для збільшення кількості російськомовних громадян, чим користується російська влада для поширення пропагандистської думки серед українського населення.

Метою статті $\epsilon$ поширення тези про вдосконалення ліберальних засад вирішення національного та мовного питання в Україні з урахуванням досвіду державотворення.

У період Української революції вирішення українського національного питання було пов'язане з необхідністю регулювання відносин із Тимчасовим урядом. На Всеукраїнському національному конгресі 5-7 квітня 1917 р. було вперше поставлено це питання, і представники Української Центральної Ради дотримувалися до прийняття IVУніверсалу автономістських принципів у рамках можливого проголошення федеративного устрою Російської республіки ${ }^{15}$.

На вирішення національного питання в Україні здійснювала вплив не лише політика Української Центральної Ради, а й позиція більшовиків, Тимчасового уряду та чорносотенних організацій. Представники імперської еліти вважали, що української нації насправді немає, та підкреслювали, що українці відіграють деструктивне значення, а вся народність повинна підлягати знищенню та інтегруватися до російського державотворення 16.

Принцип питання національних меншин заперечував гасло М. Міхновського «Україна для українців». М. Грушевський засуджував прояви національної нетерпимості й екстремізму, робив усе можливе для нормалізації міжетнічних відносин в Україні.

На початку квітня 1917 р. на засіданнях Всеукраїнського національного конгресу ці думки було розвинуто у виступі Ф. Матушевського про права нацменшин. У своєму рефераті «Автономія широка і обмежена, національно-територіальна й національна. Домагання широкої національно-територіальної автономії України і права національних меншостей та їх забезпечення» він головну увагу зосередив на висвітленні питання про їх права. Відзначаючи, що питома вага корінного населення значно вища, Ф. Матушевський наголошував, що вільна автономна Україна водночас має стати повним гарантом забезпечення всіх прав нацменшин, їх самоуправління у волостях і селах, рівноправності всіх громадян перед законом. Наприкінці доповідач запевнив, що Україна не допустить проявів шовінізму та ненависті, ніколи не буде гнобителькою тих народів, котрі проживають на їі території17.

Вирішення мовного питання Українською Центральною Радою відбувалося за погодженням із Тимчасовим урядом. 1 червня 1917 р. відбувся з'їзд Тимчасового уряду, згідно з рішенням якого Українська Центральна Рада могла використовувати українську мову за умови законодавчого захисту російської мови, тим самим підкре-

\footnotetext{
14 Матета О.А., Доскач О.С. Мовна політика в Україні: національна політика в Україні: національна консолідація чи політичний ризик // Історико-політичні студії. 2013. № 1. С. 113-122.

15 Винниченко В. Відродження нації. Ч. І... С. 87-88.

16 Ibid. C. 103.

17 Устименко В.М. Формування правничої бази... С. 82.
} 
слюючи залежність мовного питання на всій території Російської імперії від політики Тимчасового уряду. Навчання українською мовою дозволялося на рівні початкової школи, передбачалося надання «провінціальної автономії»18.

Питання національних меншин у сфері освіти вирішувалося шляхом українізації навчальних закладів із метою збереження суверенітету. Основними моментами політики Української Центральної Ради були підтримка української інтелігенції та дозвіл міністра освіти у Петрограді викладати рідну мову та літературу, історію та географію України. Відбувалося розширення мережі народних університетів в Одесі, Києві, Полтаві, Миколаєві, Харкові; національних вищих навчальних закладів в Умані та Кам'янець-Подільському; Української науково-педагогічної академії, де засновувалися кафедри українознавства. Відбувалася підготовка нових кваліфікованих кадрів та вводилося обов'язкове викладання української мови у всіх університетах України. Однак у липні 1917 р. реакційне керівництво Київського університету св. Володимира виступила проти національно-демократичних перетворень та обов'язкового викладання українською мовою, що стало базою поширення сепаратистських ідей ${ }^{19}$.

Питання національних меншин у період Центральної Ради стосувалося створенням умов для надання владних повноважень не лише українцям, а й представникам інших націй і народностей. 2 серпня 1917 р., згідно з рішенням комісії в справі розподілу місць у Центральній Раді між представниками польських та єврейських організацій, польським політичним партіям (Польська партія соціалістична, фракція соціалістів-революціонерів, Демократичний централ) було розподілено 20 місць, а єврейським політичним партіям - «Бунд», СЄРП, сіоністи, «Поалей Ціон», ПЄДС 50 місць $^{20}$. Особливістю збереження державності в період Української Центральної Ради є спроби запобігання більшовицької агітації та пропаганди 21.

Національне питання регулювалося у період Центральної Ради Законом про національно-персональну автономію 9 січня 1918 р., який був створений Національним союзом - органом, що вирішував національне питання в Україні. Передбачалися різні механізми запровадження нормативно-правового акта. Якщо українці, росіяни та поляки отримали національну автономію безпосередньо силою цього закону, то представники інших націй - білорусів, чехів, молдаван, німців, татар, греків і болгар - повинні були надіслати заяву до Генерального суду з підписом не менше 10 тис. осіб незалежно від статі та віросповідання, яка розглядалася протягом 6 місяців. Складався національний кадастр для фіксування списку 22.

Національне питання періоду Гетьманату Павла Скоропадського зумовлювалося прихильністю гетьмана до російської культури та відповідних цінностей і родового походження з української козацької еліти, яка, згідно зі словами гетьмана, поважала українські традиції 23.

Вирішення питання українсько-російських відносин у період Гетьманату передбачало два напрями. Першим була необхідність домовитися з представниками Укра-

\footnotetext{
18 Яневський Д. Політичні системи України 1917-1920 років...

19 Давидова Н.В. Наукова інтелігенція у впровадженні української мови у вищі навчальні заклади за українських урядів у 1917-1920 рр. // Емінак. 2007. № 1 (липень-вересень). С. 52-59.

20 Українська Центральна Рада... Т. 1: 4 березня - 9 грудня 1917 р....

21 Винниченко В. Відродження нації. Ч. ІІ. Київ-Відень: Видавництво «Дзвін», 1920. 328 с.

22 Українська Центральна Рада... Т. 2: 10 грудня 1917 - 29 квітня 1918 р. С. 100.

23 Скоропадський П. Спогади... С. 14.
} 
їнського національного союзу (згодом Директорією) та очолити українських національний рух. Однак П. Скоропадський обрав другий спосіб, орієнтуючись на російську еліту та проголошення створення 14 листопада 1918 р. федерації Росії з Україною, незважаючи на виконання умов сепаратного для РСФРР Берестейського договору24. У період Гетьманату російська еліта дотримувалася ідей шовінізму, вважаючи українську націю продуктом німецької думки й австрійської агітації, однак П. Скоропадський враховував досвід представників імперської влади для управління державою25.

Незважаючи на консервативність ідеології, уряд гетьмана намагався усунути міжнаціональні розбіжності. Здійснювалися спроби усунення дискримінаційних положень системи освіти Російської імперії відносно національності вступників до університетів, тому продовжувалася українізація освіти 26.

Демократичним шляхом також вирізнялася етнонаціональна політика Західноукраїнської Народної Республіки. Проголошувалися соціальна та економічна рівність всіх громадян, рівність їх перед законом незалежно від національності, мови, конфесійної належності, представництво національних меншин в уряді27.

Директорія після приходу до влади прагнула залучити представників національних меншин до органів державної влади УНР, однак не було членів польських і російських організацій 28. Так, на засіданні 13 лютого 1919 р. відбулося слухання доповіді державного секретаря щодо постанови Директорії про асигнування 3 млн. карбованців для видачі допомоги єврейському населенню різних міст і містечок, які постраждали від єврейських погромів з такими змінами: замість 3 млн. карбованців виділити 1 млн. карбованців, у кінці додати «і під контролем місцевих рад» - органів місцевої влади УНР. Директорія УНР зумовила можливість підтримки єврейства, однак під питанням залишалося запобігання знищення євреїв та їх майна29.

У період існування Директорії більшовики, есери та білогвардійці звинувачували отаманів, у тому числі С. Петлюру, в погромах євреїв. В. Винниченко підтримував вказану репутацію з огляду на думку керівника Директорії про прихильність євреїв до комуністичної партії. Однак у «Віснику УНР» наведено наказ 20 липня 1919 р., в якому вказувалося, що євреї допомагають у протистоянні більшовикам, а сам С. Петлюра був нейтральним щодо погромщиків, однак відбувся арешт погромщика Симосенка. Були приклади допомоги єврейських жінок українським пораненим 30 .

У виборах до Трудового Конгресу брали участь українські партії та партії єврейської, польської та російської національних меншин. Для регулювання питань із захисту прав євреїв існувало міністерство єврейських справ УНР. Для поляків і росіян такі органи не створювалися, однак представники вказаних національних меншин підтримували Польщу та більшовицьку Росію у зовнішньополітичних питаннях 31. Директорія здійснювала спроби відновити національно-персональну автономію та розраховувала на прихильність національних меншин. Однак реально відродження

24 Ibid. C. 24.

25 Скоропадський П. Спогади... С. 48.

26 Давидова Н.В. Наукова інтелігенція у впровадженні української мови... С. 54.

27 Яневський Д. Політичні системи України 1917-1920 років... С. 271.

28 Устименко В. Етнополітичний фактор в політиці Директорії УНР... С. 210.

29 Директорія, Рада Народних Міністрів Української Народної Республіки. Листопад 1918 - листопад 1920 рр.... Т. 1. С. 261.

30 Винниченко В. Відродження нації... Ч. ІІІ. С. 367-368.

31 Устименко В. Етнополітичний фактор в політиці Директорії УНР... С. 212. 
автономії стосувалося лише єврейської народності шляхом поновлення Міністерства єврейських справ. Міністерства російської та польської національних меншин поновлені не були ${ }^{32}$.

На думку В.Устименка, незважаючи на антисемітизм Директорії УНР, уряд виділяв кошти та здійснював захист євреїв. 27 травня 1919 р. була утворена Особлива слідча комісія з розслідування випадків погромів та антисемітської агітації, притягнення винних у погромах до відповідальностіз3.

У період Директорії УНР вирішувалося питання українізації російських університетів у плані змін кваліфікованих кадрів, які не бажали розмовляти українською мовою, однак через наступ російських військ політика не набула логічного завершення 34 .

На сучасному етапі Україна питання національних меншин визначає потребами збереження української мови та запобіганню дискримінації, забезпечення прав і обов'язків етнічних груп, зокрема росіян, білорусів, молдаван, греків, татар та інших у рамках унітарної держави, необхідністю зберегти національну безпеку та вирішення конфліктів між органами влади ${ }^{35}$, глобалізацією як уніфікацією населення та поширенням демократичного руху під впливом духовного відродження, а також присутністю великої частки окремих національних меншин в окремих регіонах ${ }^{36}$.

Впровадження російської мови, як другої державної, в Україні становить загрозу для державності. 3 цього погляду необхідно вирішувати дві проблеми. Першою деталлю $є$ висока частка росіян і російськомовних українців в Україні: українською мовою спілкувалося близько 53\% громадян України, російською - 45\%. Другим аспектом питання $є$ проблема поширення мов національних меншин ${ }^{37}$. Дані соціологічних опитувань, проведені у 2017 р. центром Разумкова, свідчать про моноетнічність української нації: українцями вважаються 90,6\%, росіянами - 6,3\%, представниками національних меншин - 2,7\%

Сучасне українське законодавство керується Гельсінкським заключним актом (1975), згідно з яким існує принцип поваги до національних меншин в європейських країнах, у тому числі в Україні. Віденська зустріч (1989) декларувала підтримку для збереження ідентичності національних меншин (ст. 19), рівноправність громадян України (ст. 31), обмін інформацією рідною мовою (ст. 45), право на розвиток культурної спадщини (ст. 59), право на навчання в рамках власної культури (ст. 69). Копенгагенська нарада (1990) передбачає низку прав та обов'язків представників національних меншин, які зумовлюють вдосконалення ліберальних засад, зокрема, можливість створення культурних і релігійних установ, вільного віросповідання та зв'язків з іншими країнами, створення організацій, заохочення етнічної та релігійної самобутності ${ }^{39}$.

\footnotetext{
32 Ibid. C. 214.

33 Устименко В. Етнополітичний фактор в політиці Директорії УНР... С. 231.

34 Давидова Н.В. Наукова інтелігенція у впровадженні української мови... С. 56.

35 Абрамова Д. Правове регулювання державної мовної політики... С. 228.

36 Ibid. C. 230-231.

37 Матета О.А., Доскач О.С. Мовна політика в Україні... С. 118.

38 Підбережник Н. Нормативно-правова база публічного управління 3 врегулювання етнополітичних відносин в Україні // Ефективність державного управління. 2017. Вип. 2 (51). Ч. 1. C. 152.

39 Глотов Б. Європейські нормативно-правові засади державного регулювання етнонаціональної сфери та їх імплементація в українському законодавстві // Державне управління та місцеве самоврядування. 2017. Вип. 2 (33). С. 57.
} 
Питання національних меншин частково визначається нормативно-правовими актами та рекомендаціями міжнародних структур, що регламентують права етнічних громад (резолюції Організації Об'єднаних Націй (OOH) та ПАРЄ, а також рекомендації ОБСЄ). 3 базових документів ООН у цій сфері прийнято дві декларації: Декларація принципів толерантності» та «Декларація про права осіб, що належать до національних або етнічних, релігійних та мовних меншин»40.

Згідно з «Декларацією принципів толерантності» Україні, як і іншим державам світу, необхідно запобігати проявам тероризму та здійснювати допомогу мігрантамбіженцям і забезпечувати працевлаштування трудовим мігрантам, підтримувати розвиток демократії. Законодавство передбачає принципи терпимості (стаття 1), плюралізм та обмеження насильства з переліку можливих засобів вирішення міжнаціональних питань (стаття 2), необхідності виховання мирних відносин (стаття 4). Відбулося проголошення 16 листопада як дня міжнаціональної терпимості ${ }^{41}$.

«Декларація про права осіб, що належать до національних або етнічних, релігійних та мовних меншин» передбачає створення умов для рівних гендерних відносин. Закон декларує збереження самобутності (стаття 1), свободу віросповідання (стаття 2), можливість національних меншин брати участь в економічному розвитку своєї країни (стаття 4), врахування інтересів національних меншин при здійсненні національної політики (стаття 5) ${ }^{42}$.

Вирішення національного питання втілюється нормами європейського законодавства, зокрема, Рамковою конвенцією про захист національних меншин, Європейської хартії регіональних мов або меншин і низки інших міжнародних договорів 43 .

Вирішення питання національних меншин згідно з Рамковою конвенцією про захист національних меншин повинне відбуватися згідно зі співробітництвом України з міжнародними організаціями й іншими країнами, які укладають законодавство про правові акти. Законодавство зумовлює утвердження ліберальних засад етнополітики та дозволу мирних контактів національних меншин із населенням рідних країн, заборону національної дискримінації, створення умов для збереження самобутності, вільного вибору поглядів і віросповідання, безперешкодне використання мов національних меншин. Стаття 15 передбачає право представників національних меншин бути обраними до органів влади ${ }^{44}$.

В Європейській хартії регіональних мов або меншин вказано, що збереження мов національних меншин сприяє збереженню культурної спадщини та не повинне зашкодити розвитку офіційної мови. У будь-якій державі, де діє вказаний нормативноправовий акт, потрібно підтримувати культурні відносини між національностями. Важливо зберігати рівність між громадянами України. Передбачені такі права наці-

\footnotetext{
40 Гбур 3.В. Національна безпека країни через призму захисту національних меншин // Інвестиції: практика та досвід. 2018. № 9. С. 104.

41 Декларація принципів толерантності...

42 Декларація про права осіб, що належать до національних або етнічних, релігійних та мовних меншин / Прийнято резолюцією 47/135 Генеральної Асамблеї ОOH від 18 грудня 1992 року. URL: https://zakon.rada.gov.ua/laws/show/995_318

43 Вітман К.М. Модернізація законодавства про національні меншини в Україні // Наукові праці Національного університету «Одеська юридична академія». 2013. Т. 13. С. 166; Косьмій О., Кравченко Ю. Нормативно-правове забезпечення діяльності етнокультурних меншин в Україні та Польщі // Studia politologica Ucraino-Polona. 2013. Вип. 3. С. 95.

44 Друга доповідь України про виконання Рамкової конвенції Ради Європи про захист національних меншин. Київ, 2006. С. 37.
} 
ональних меншин, як здобуття освіти рідною мовою, проведення судових справ, свободу прийняття трансляцій через засоби масової інформації відомості з інших країн ${ }^{45}$.

Права національних меншин згідно з Гаазькими рекомендаціями щодо прав національних меншин на національну освіту забезпечували повне та вільне становлення людської особистості в умовах рівноправності й орієнтовані на розвиток громадянського суспільства. Громадяни України повинні володіти державною мовою та користуватися нею у державних установах. Держава має забезпечувати впровадження та вдосконалення програм освіти для національних меншин, виконання адміністративних вимог і право меншин створювати власні навчальні заклади ${ }^{46}$.

В Україні правовий статус національних меншин регламентується Конституцією України, законами України «Про національні меншини в Україні», «Декларація про державний суверенітет України», «Конституцією України», Декларацією прав національностей України ${ }^{47}$.

У практиці українського законодавства вперше поняття «національна меншина» було використано в Законі «Про національні меншини в Україні» від 25 червня 1992 р. У статті 3 цього закону національні меншини визначені як «групи громадян, які не є українцями за національністю, виявляють почуття національного самоусвідомлення і спільності між собою»48.

Як вважає Н. Шипка, національна меншина має чітко окреслений статус в Україні. Головною ознакою вказаної групи осіб є здатність до самовідтворення. Власне самовідтворення виявляється у передачі наступним поколінням етнічної самосвідомості, самоідентифікації, збереження кількісного складу групи впродовж тривалого часу та наявності етнічних інституцій, які є посередниками між меншиною та суспільством загалом (національно-культурні товариства, засоби масової інформації та система освіти). На цій основі виокремлюються такі визначальні характеристики національних меншин: спільні стійкі етнічні ознаки, перебування у конкретній суверенній державі за наявності власної історичної батьківщини, взаємодія з іншими етнічними групами країни за принципами проживання «ми - вони»; наявність чітко визначеного статусу стосовно більшості населення; наявність власної функції у структурі поліетнічного суспільства 49 .

Першим юридичним актом незалежної Української держави, в якому зафіксовано рівні права всіх етнічних груп в Україні, стала Декларація про державний суверенітет (16 липня 1990 р.). У зверненні до громадян України всіх національностей йшлося про початок нової доби у розвитку міжнаціональних відносин в Україні. Вказувалося, зокрема, що: 1) громадяни всіх національностей складають народ України

45 Європейська хартія регіональних мов або меншин. Страсбург, 1992. C. 9. URL: http://library.khpg.org/files/docs/e15.pdf

46 Гаазькі рекомендації щодо прав національних меншин на освіту та пояснювальна записка. 1996. C. 17.

47 Ткаченко Є.В. Правовий захист прав етнічних та мовних меншин. Навчальний посібник. Київ, 2018. С. 47; Шабельник І.Ю., Устименко О.С. Право національних меншин в Україні // Матеріали Всеукраїнської науково-практичної конференції (ДДУВС, 09.02.2018). Дніпро, 2018. С. 211.

48 Гетьманчук М. Міжнародна нормативно-правова база захисту прав національних меншин в Україні // Державна політика щодо захисту прав національних меншин: досвід країн Вишеградської школи. Львів. Видавництво «Сорока», 2019. С. 30.

49 Шипка Н. Національні меншини як суб'єкти етнополітичних відносин у державотворчих процесах в Україні кінця XX ст. - початку XXI ст. // Українська національна ідея: реалії та перспективи розвитку. 2006. Вип. 17. С. 90. 
(розділ II); 2) зазначалося, що держава забезпечує рівність перед законом усіх громадян незалежно від походження, соціального і майнового стану, расової та національної належності, статі, освіти, мови, політичних поглядів, релігійних переконань, роду та характеру занять, місця проживання та інших обставин (розділ IV); 3) надавалась гарантія, що проголошення незалежності не призведе до порушення прав людини будь-якої національності, а держава забезпечить повну свободу розвитку всіх національних мов та культур (розділ VIII).

Згідно із Законом України «Про громадянство України» (8жовтня 1991 р.) громадянами України є особи, які проживали на території держави на момент здобуття незалежності, а також всі особи незалежно від раси, кольору шкіри, етнічного походження, соціально-демографічних та інших ознак, які на момент набуття чинності Закону України «Про громадянство України» (13 листопада 1991 р.) постійно проживали на території України і ніколи не були громадянами інших держав 50.

Правові засади питання національних меншин регулюються Конституцією України. Документ проголосив державу як гаранта дотримання збереження прав усіх націй, які проживають на їі території. Ліберальні засади збереження прав національних меншин висвітлені у статтях 23 і 24 Конституції України, згідно з якими людина має право на вільний розвиток своєї особистості, рівність перед законом і відсутність дискримінації щодо представників національних меншин. Стаття 35 гарантує свободу світогляду та віросповідання, статті 36 і 37 - право на політичну діяльність і створення політичних партій. Стаття 53 передбачає отримання освіти рідною мовою51.

Принципи регулювання прав національних меншин відбувається згідно з необхідністю пристосуватися до європейських норм і врахувати умови відносин між представниками різних національностей в Україні. Згідно з Законом України «Про національні меншини в Україні» (стаття 6), декларовано права представників національностей, які проживають на території України, на національно-культурну автономію, зокрема, права на наявність символіки, задоволення потреб у літературі та мистецтві тощо. Ст. 16 документа передбачає фінансування розвитку організацій і товариств національних меншин. Відповідно до статті 3 Закону України «Про місцеве самоврядування в Україні» забороняються обмеження прав національностей, що стосуються місцевого самоврядування52.

Декларація прав національностей України (1 листопада 1991 р.) передбачає, що зі статтею 2 зберігається право національних меншин на традиційне розселення та територіально-адміністративних одиниць, зі статтею 3 - вільне користування мовами національних меншин в усіх сферах життя. Декларується охорона пам'яток історії та культури народів (стаття 5), дозвіл культурного зв'язку національних меншин з історичною батьківщиною53.

Закон України «Про національні меншини» декларує забезпечення національними меншинами державного суверенітету та територіальної цілісності України (стаття 2), забезпечення підготовки спеціалістів у галузі культури серед національних

\footnotetext{
50 Шипка Н.П. Легітимація політичної суб'єктності національних меншин в Україні // Військовонауковий вісник. 2008. Вип. 10. С. 231-232.

51 Директорія, Рада Народних Міністрів Української Народної Республіки. Листопад 1918 - листопад 1920 рр.... Т. 1. С. 112.

52 Лихач Ю. Актуальні проблеми законодавчого забезпечення прав національних меншин в Україні // Наукові записки / ІПіЕНД ім. І.Ф. Кураса НАН України. 2010. Вип. 3 (47). С. 232-233.

53 Декларація прав національностей України (Ред. від 01.11.1991). URL: https://zakon.rada.gov.ua/laws/show/1771-12
} 
меншин (стаття 7), використання бюджетних коштів для фінансування діяльності національних меншин (стаття 16), встановлює відповідальність за порушення прав представників національних меншин ${ }^{54}$.

Резонансним стало прийняття Закону України «Про засади державної мовної політики», що має неофіційну назву «закон Колесніченка-Ківалова». Цей закон було прийнято 5 червня 2012 р. Голосування за нього відбувалося із порушеннями Конституції України та регламенту Верховної Ради України. Закон містив неоднозначне визначення терміна «рідна мова», трактуючи його таким чином: «рідна мова - перша мова, якою особа оволоділа у ранньому дитинстві». Водночас у ч. 1 ст. 3 вказано, що «кожен має право вільно визначати мову, яку вважає рідною». За Законом, державною мовою України є українська, але відповідно до статті 7 Закону істотно розширювалося використання регіональних мов, якщо кількість осіб-носіїв цієї мови, що проживали на території, на якій поширена ця мова, становить 10\% і більше чисельності ї̈ населення. Проте за рішенням місцевої ради в окремих випадках з урахуванням конкретної ситуації ця цифра могла бути меншою від 10\%. Розшифрування «окремих випадків» у законі не надавалося. Відповідно до Закону регіональні мови можна було використовувати у роботі, діловодстві та документації органів державної влади й органів місцевого самоврядування. Також регіональну мову дозволялося застосовувати у листуванні цих органів з органами державної влади вищого рівня. Законом також гарантувалося право отримання освіти регіональними мовами, зокрема, і вищої освіти. Лише у збройних силах України й інших військових формуваннях, створених відповідно до законодавства України, повинна була панувати державна мова55.

Закон України «Про забезпечення функціонування української мови як державної» (2019 р.) передбачає поширення української мови як державної мови та засобу міжетнічного спілкування. Стаття 5 нормативно-правового акта передбачає створення державної програми опанування української мови. Обмежується застосування мов інших національностей, які проживають на території України ${ }^{56}$. Відповідно до законодавства було прийнято Постанову Кабінету Міністрів України від 22 травня 2019 р. «Питання українського правопису», згідно з якою схвалено нову редакцію правопису, розроблену Українською національною комісією з питань правопису і яка повинна використовуватися у діловодстві, освіті, видавничій справі, сфері телебачення та радіомовлення, інших сферах суспільного життя57.

Важливе значення у вирішенні питання національних меншин у сучасній Україні $\epsilon$ реалізація прав та обов'язків громадян держави, в тому числі кримських татар. Голова Меджлісу кримськотатарського народу Мустафа Джемілєв на Першому кримськотатарському конгресі 19 травня 2009 р. підкреслював значення ініціативи національності у збереженні української державності. Проблема кримських татар зумовлена можливістю повернення кримських татар до Криму та вирішення питань приватизації, зайнятості, нерозвиненої інфраструктури, культурно-освітньої діяль-

\footnotetext{
54 Закон України «Про національні меншини» // Відомості Верховної Ради України. 1992. № 36. C. 529.

55 Матета О.А., Доскач О.С. Мовна політика в Україні... С. 118-119.

56 Закон України «Про забезпечення функціонування української мови як державної» // Відомості Верховної Ради. 2019. № 21. С. 81.

57 Постанова Кабінету Міністрів України «Питання українського правопису» / Редакція №437 від 22 травня 2019 p. URL: https://zakon.rada.gov.ua/laws/show/437-2019-п\#Text
} 
ності та історичної пам'яті, земельна проблема. Недоліком вирішення питань кримських татар є недооцінка значення політико-правових питань, пов'язаних із визнанням меджлісу як політичної організації58.

Отже, вирішення національного та мовного питання в період Української революції та на сучасному етапі в умовах збереження суверенітету зазнали впливу російськомовності. Зважаючи на цей факт, потрібно зауважити, що поширення української мови зумовлюється законодавчою декларацією та практичним втіленням поваги до державної мови та забезпеченням вільного вивчення української мови. Якщо в період Української революції відбувався відхід від домінування російської мови та було взято курс на рівність національних меншин, то на сучасному етапі відбувається не лише залучення національностей до співпраці з органами державної влади, а й заохочується збереження самоідентифікації національностей, вдосконалено демократизацію та формується більш чітка державотворча позиція щодо спроб ухвалення проросійських законів. Якщо українські уряди в 1917-1923 рр. не змогли провести радикальні дії повністю з погляду на воєнні дії, навіть розуміючи необхідність проведення українізації мовної і національної політики, то поміркованість українських урядів щодо вирішення мовного та національного питання на сучасному етапі допомагає залучити до державотворення національні меншини і, водночас, заважає запобігати збереженню високого відсотка російськомовності.

\section{REFERENCES}

Abramova, D. (2019). Pravove rehuliuvannia derzhavnoi movnoi polityky u sferi zahystu prav natsionalnykh menshyn [Legal regulation of the State language policy in the field of protection of the rights of national minorities]. Heopolityka Ukrainy: istoriia i suchasnist. Zbirnyk naukovyh prats, 1 (22), 226-261 [in Ukrainian].

Davydova, N. (2007). Naukowa intelihentsiia u vprovadzhenni ukrainskoi movy u vyshchi navchalni zaklady za ukrainskyh uriadiv u 1917-1920 rr. [Scientific intelligentsia in the introduction of the Ukrainian language in higher educational institutions under the Ukrainian governments in 19171920]. Eminak, 1 (lypen-veresen), 52-59 [in Ukrainian].

Hbur, Z. (2018). Natsionalna bezpeka krainy cherez pryzmu zakhystu natsionalnykh menshyn [National security of the country through the prism of protection of national minorities]. Investytsii: praktyka ta dosvid, 9, 103-107 [in Ukrainian].

Hetmanchuk, M. (2019). Mizhnarodna normatyvno-pravova baza zakhystu prav natsionalnykh menshyn v Ukraini [International legal framework for the protection of the rights of national minorities in Ukraine]. In Derzhavna polityka shchodo zakhystu prav natsionalnykh menshyn: dosvid krain Vyshehradskoi shkoly, (pp. 27-36). Lviv: Vydavnytstvo «Soroka» [in Ukrainian].

Hlotov, B. (2017). Evropeiski normatyvno-pravovi zasady derzhavnoho rehuliuvannia etnonatsionalnoi sfery ta yih implementatsiia v ukrainskomu zakonodavstvi [European legal principles of State regulation of the ethno-national sphere and their implementation in Ukrainian legislation]. Derzhavne upravlinnia ta mistseve samovriaduvannia, (2 (33)), 56-63 [in Ukrainian].

Kalakura, 0. (2000). Pravovyi status etnichnyh menshyn Ukrainy [Legal status of ethnic minorities in Ukraine]. Etnichna istoriia Evropy, (4), 109-114 [in Ukrainian].

Kosmii, O. \& Kravchenko, Yu. (2013). Normatyvno-pravove zabezpechennia diialnosti etnokultyrnykh menshyn v Ukraini ta Polshchi [Regulatory and legal support of ethnocultural minorities in Ukraine and Poland]. Studia politologica. Ucraino-Polona, (3), 94-99 [in Ukrainian].

Lyhach, Yu. (2010). Aktualni problemy zakonodavchoho zabezpechennia prav natsionalnykh menshyn v Ukraini [Current problems of legislative provision of the rights of national minorities in Ukraine]. Naukovi Zapysky, 3 (47), 27-37 [in Ukrainian].

Mateta, O.A. \& Doskach, O.S. (2013). Movna polityka v Ukraini: natsionalna polityka v Ukraini: natsionalna konsolidatsiia chy politychnyi ryzyk [Language policy in Ukraine: national policy in

58 Тищенко Ю. Процес повернення та кримські татари в Україні // Часопис Ї. Кримські татари. Довге повернення. 2018. № 90. С. 98. 
Ukraine: national consolidation or political risk]. Istoryko-politychni studii, (1), 113-122 [in Ukrainian].

Pidberezhnyk, N. (2017). Normatyvno-pravova baza publichnoho upravlinnia z vrehuliuvannia etnopolitychnykh vidnosyn v Ukraini [Legal framework of public administration for the settlement of ethnopolitical relations in Ukraine]. Efektyvnist derzhavnoho upravlinnia, 2 (51), Vol. 1, 151-159 [in Ukrainian].

Shabelnyk, I. \& Ustymenko, O.S. (2018). Pravo natsionalnykh menshyn v Ukraini [The right of national minorities in Ukraine]. Abstracts of Papers: Vseukrainska naukovo-praktychna konferentsiia, (pp. 211213). Dnipro [in Ukrainian].

Shypka, N. (2006). Natsionalni menshyny yak subiekty etnopolitychnykh vidnosyn u derzhavotvorchykh protsesakh v Ukraini kintsia XX - pochatky XXI st. [National minorities as subjects of ethnopolitical relations in state-building processes in Ukraine at the end of the XX - the beginning of the XXI century]. Ukrainska natsionalna ideia: realii ta perspektyvy rozvytku, (17), 89-94 [in Ukrainian].

Shypka, N. (2008). Lehitymatsiia politychnoi subiektnosti natsionalnykh menshyn $v$ Ukraini [Legitimation of the political subjectivity of national minorities in Ukraine]. Viiskovo-naukovyj visnyk, 10, 229-240 [in Ukrainian].

Skoropadskyi, P. (1995). Spohady. Kinets 1917 - hruden 1918 [Memories. End of 1917 - December 1918]. Kyiv-Filadelfiia [in Ukrainian].

Smolii, V.A. (Ed.) \& Verstiuk, V.F. (Comp.) (1997). Ukrainska Tsentralna Rada. Dokumenty i materialy [Ukrainian Central Rada. Documents and materials]. Volume 1-2. Kyiv: Naukova dumka [in Ukrainian].

Tyshchenko, Yu. (2018). Protses povernennia ta krymski tatary v Ukraini [Return process and Crimean Tatars in Ukraine]. Chasopys «ï». Krymski tatary. Dovhe povernennia, (90), 92-102 [in Ukrainian].

Tkachenko, Ye. (2018). Pravovyi zahyst prav etnichnykh ta movnykh menshyn [Legal protection of the rights of ethnic and linguistic minorities]. Kyiv [in Ukrainian].

Ustymenko, V. (2010). Etnopolitychnyi faktor v politytsi Dyrektorii UNR [Ethnopolitical factor in the policy of the Directory of the Ukrainian People's Republic]. Problemy vyvchennia istorii Ukrainskoi revoliutsii 1917-1921 rokiv, 5, 207-256 [in Ukrainian].

Ustymenko, V. (2012). Formuvannia pravnychoi bazy dlia rehuliuvannia mizhetnichnykh vidnosyn u period Ukrainskoi Tsentralnoi Rady [Formation of the legal basis for the regulation of interethnic relations during the period of the Ukrainian Central Rada]. Ukrainskyi istorychnyi zhurnal, 1, 79-88 [in Ukrainian].

Verstiuk, V. (Comp.) (2006). Dyrektoriia, Rada Narodnykh Ministriv Ukrainskoi Narodnoi Respubliky. Lystopad 1918 - lystopad 1920 rr.: Dokumenty i materialy [Directory, Council of People's Ministers of the Ukrainian People's Republic. November 1918 - November 1920: Documents and materials]. Vol. 1. Kyiv: Vydavnytstvo imeni Oleny Telihy [in Ukrainian].

Vitman, K. (2013). Modernizatsiia zakonodavstva pro natsionalni menshyny v Ukraini [Modernization of legislation on national minorities in Ukraine]. Naukovi pratsi, (13), 166-174 [in Ukrainian].

Vynnychenko, V. (1920). Vidrodzhennia natsii [Revival of the nation]. Kyiv-Viden: Vydavnytstvo «Dzvin» [in Ukrainian].

Yaanevskyi, D. (2003). Politychni systemy Ukrainy 1917-1920 rokiv: sproby tvorennia i prychyny porazky [Political systems of Ukraine in 1917-1920: attempts to create and causes of defeat]. Kyiv: Dukh i Litera [in Ukrainian].

\section{Yuliia Liebiedieva}

(Research Institute of Ukrainian Studies, Kyiv, Ukraine)

e-mail: lebedeva-yuliya@ukr.net

ORCID: https://orcid.org/0000-0003-0628-0309

\section{Problem of National Minorities and Language Issue During Ukrainian Revolution and in Modern Independent Ukraine}

The paper evolves a thesis on the conditionality of the national minorities problem during the Ukrainian national revolution and in independent Ukraine by the need to preserve the self-identification of both Ukrainians and other national minorities at the present stage in terms of preserving statehood. The dependence of the solution of the issue of national 
minorities in the Ukrainian National Republic on the position of the Provisional Government and the Bilshovyks is pointed out.

The existence of the principle of resolving the issue of national minorities through the development of liberal principles in the conditions of autonomy is emphasized. It is noted that during the autonomy of the Ukrainian Central Rada there was a restriction on the use of Ukrainian language. It is pointed out that national minorities were allowed to influence the division of their own powers. The existence of differences in rights between certain nationalities, which determined different mechanisms of interference in state affairs, is confirmed.

The relevance of Russian elite in resolving the issue of national minorities during the Hetmanate of Pavlo Skoropadskyi and the democracy in resolving the issue of Jewish pogroms initiated by the Bilshovyks are noted.

Factors influencing the elimination of differences in the national issue in independent Ukraine at the present stage are identified. The global, regional, and national levels of legislation governing the solution of national minorities are highlighted.

It is pointed out that there is a possibility of peaceful prevention of conflicts on the language issue, preservation of the identity of national minorities, and influence on Ukraine's path of development. The untrammeled development of national organizations in Ukraine at the present stage and the importance of personal development are emphasized.

Ukrainian legislation draws attention to the multi-aspect essence of the notion of national minorities as a Ukrainian society component. The application of liberal principles as a way to solve the issue of national minorities is emphasized. The practical realization of the language and national issue gives the opportunity for productive cooperation between the bodies of state power and national minorities.

Keywords: national minorities, language issue, Ukrainian revolution, independent Ukraine, democracy, liberal principles 